82

類學に於て極めて役立つものである事を 認めるであらうと著者は結論してみる が、いづれにしても㔹法論上つ論議は今 後時日を街つて解決せらるべき問題であ らう。(宮內)

\section{中谷治宇二郎 日本先史學序史}

本書は多年に瓦り痛床生活を續けてる る中谷氏の近菼である。內容は大體明治 以前の文書に記載された土器石器等の先 史時代遺物關係の重項を蒐集網羅して黄 正なる先史考古學發生以前の人々が如何 に之等の物を觀察し、解釋したかと云ふ ことを巧妙なる筆致で記したるのであ る。同氏の斯方面への興睏は「日本石器 時代文獻目錄」（昭和 4 年）緍篹當時から であつて、之に關する三三の文章む畫い てみるが、本書ではそれを擴大し、資料

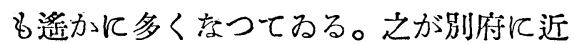
以邊僻を出舍で起居も意に任せ奴病人の 手に成つたものである。何時も乍ら同氏 の熱意と練㯇とに警かされるのである。 しかもそれを單なるディレッタンティズ 云に除サしめず、一應は氏の文化图說の 資料として探り、從來氏が發表したもの と對比するあたり、研究熱の旺盛なるこ とを示して居る。吾々は本書によつて明 治以前の古物研瑩儿就ての大要を知り得 る便を得たかけである。

最後に同氏の努力に對して敬意を表す ると共に、今後も益々自重して明治以後
㫪

の本格的先史學史を成されんととを耎る 咨第である。

菊判本文 243 面、文獻目錄 9 面、年謵 8 頁、染引17貲、插畫74。定價 2.50圓、 東京市神田一ッ橋 岩波書店刊 (八幡)

\section{Mackay, e, The Fnaus Civilizadion,}

London, 1935. Pp. $210+16$ pls. 6 s.

英國印度政聽が1922年か.ら1927年に互 つて、Indus 河畔つ Mohenjo-Daro 及 び Harappa に於いて考古學的發掘を行 つて、Aryan 民族与居以前に於ける都 城の潰址を發見したととは、學照媓に著 明な事柄であり、及此の調查の指導者た る JoHn MARSHALL 卿が 1931年に發掘 の成果を 3 册の豪龩な報告書として作り 上げて刊行されたてとも本譩に已に紹介 したところである。

併しながら、此の報告書が龙大なるも のであるために、普及さるるととが少 く、從つて專門の學徒以外には Indus 河畔の古代の文化概擎さへも殆んよ゙知ら れることが無かつた憾みがあつたのであ る。されば、今回同地にあつて、長い間 發掘に從事して居た MACKAY Eが、此 の發掘、調㮅嵓に研究に基いて Indus 文明の概要を、簡單に縓めて出版された ことは、藍し時宜を得たものと云ふべき である。加之、同氏は、前揭 MARSHALL 卿の報告書のうち、建筑・日営用具・服 飾具・印章・土器・石製容器・銅器及び 
青銅器等に關するものを執筆されを學者 であり、叉 Mesopotamia, Egypt 站に Palestine 等に就いての考古學者として も有名であるから、本書の著者としても 申分の無いところであらら。いま目炏を 示すと。

I. The Indus Civilization.

II. Architecture and Masonry.

III. Religion.

IV. Diess and Personal Ornaments.

V. Copper and Bronze.

VI. Arts and Crafts.

VII. Customs and Amusements.

VIII. Chronology and Connections with Other Countries.

の如くで、痤かに Bibliography と地圖 圖版が17葉收めてある。一つ一つを前揭 の報告書と比較して異同を述べる睱も無 いが、從來 Mohenjo-Daro 及び Harappa の文朋を、金不併用期飞屬するもの と認め、その年代を大凡紀元前 4000一 3000年頃のものと推测して居たとてろで あるが、本畫に於んては、青銅器時代に 屬すべきものと主張し、彼の銅器と件出 する細石器類の如きは金屬の代用として 俅用したものであつて、決して、乙れを 以つて金石併用期たるの登據となし得な レととを記し、叉其の年代の如きも紀元 前 3000-2500 年頃に當るであらうと憶 测してある。其の他か Mesopotamia と の交通の痤かに中央丝細亞の高原との交
涉の存したららと云ふてとを述べて居る 等注意すべきとてろであらう。

以上まことに簢單な紹介であるが、本 書が Indus 文明の概觀を筧ふべき好著 であることは何人も首肯するとてろであ らう。我及は我が國に於いても考古學的 發掘調查の㪕告書に豪荬なるものが刊行 されると其に、適當な學者によつて、斯 くの如を麻價便利を著書の出顯されると とを希跓するものである。(駒井)

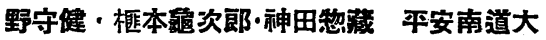
同郡大同江面梧野里古填調查報告 朝鮮總督 府炤和 5 年度古蹟調查報告 第 1 册 朝鮮平安南道大同江面の樂浪時代の古 填が漢代文化の毭庫であることは今更ら 云ふまでもない。併し、樂浪古墳に關す る新しい報告書が世に出るごとに、益々 その感を深くするものは獨り私のみでは あるまい。本書に報告された大同江面梧 野里の第19號墳の如きも眞に警嗼すべき 漢代文化の冈容を示現した。

本書は梧野里に於ける 4 古填、即ち第 18 ・第19・第20號填を本論に於んて、第 21號填を附錄に於いて報告してるる。而 して、それらの古填の發見の契機は、昭 和 5 年11月、當地のコーン・プロダクショ ン會社社宅の基礎工事中偶然 1 基の木㯕 填の暴露されたのに發すると云ふ。

第18號填は既に盜掘の厄に會ひ、樹材・ 棺材の全部が壙外に運び出され、遺物も 